\title{
SEARCHING FOR THE HOLY SPIRIT IN THE EPISTLE OF JAMES

\author{
IS ‘WISDOM’ EQUIVALENT?
}

William R. Baker

\begin{abstract}
Summary
The search for the Holy Spirit in James often stops with Kirk's article 'The Meaning of Wisdom in James: An Examination of a Hypothesis' published in 1969, which contends that the way in which James uses wisdom is more or less interchangeable with that in which other writers of the New Testament use the concept of the Holy Spirit.' This paper examines Kirk's position and arguments closely as a window into the question of whether wisdom in James should be read as equivalent to the Holy Spirit elsewhere in the NT. The basic conclusion is that Kirk (followed by Davids) has made the case for the importance of Jewish wisdom theology to James but his tantalising claims have too often not been read in the light of his sobering conclusions. At times, he has overlooked important correspondence to the Jesus tradition and has made too much of correspondences to Pauline writings. James' orientation toward wisdom is without regard to the Holy Spirit as developed in Paul or elsewhere in the New Testament. It should be read as aligning somewhere between Septuagintal wisdom literature and the Jesus tradition.
\end{abstract}

\section{Introduction}

The Epistle of James is the only NT document other than the unusually brief letters of 2 and 3 John and Philemon that does not refer explicitly to the Holy Spirit. It does include two references to $\pi v \varepsilon \tilde{u} \mu \alpha$. However, the first, in 2:26, being in juxtaposition with 'body', surely refers to the human spirit. Though more contentious, the second, in 4:5, favours a reference to the human spirit as well, either in the positive sense of the 
creative spark God put in man that longs for him or in the negative sense of the evil tendency of the human spirit that envies after the possessions of others. ${ }^{1}$

This theological deficit in James is akin to Luther's heavily repeated concern about the epistle's hollowness due to its failure to articulate a gospel message that expounds justification by faith alone. It is also related to the limited christology in James that focuses on Christ's eschatological return as judge, loyalty to his 'name', and his 'glorious' resurrected relationship to God. ${ }^{2}$ Absent is anything of the cross and its role in making possible a new, saving relationship with God. ${ }^{3}$

The search for the Holy Spirit in the Epistle of James for the most part begins and ends with Kirk's article 'The Meaning of Wisdom in James: An Examination of a Hypothesis' published in 1969. This was a groundbreaking article that rightfully placed James in the context of Jewish wisdom theology. However, it strains to demonstrate its extravagant claim that the way James employs wisdom 'is more or less interchangeable with that in which other writers of the New Testament use the concept of the Holy Spirit.' ${ }^{4}$ Subsequent discussions of the issue invariably reference Kirk, as they should, but they do not engage the article's substantive arguments. Nor do they usually see that in spite of his claims within the article that one should identify wisdom in James as equivalent to the Holy Spirit, in his conclusion even he is

1 On the positive view, which I favour, see Sophie Laws, A Commentary on the Epistle of James (BNTC; London: Adam \& Charles Black, 1980): 174-79; Sophie Laws, 'Does Scripture Speak in Vain? A Reconsideration of James IV.5', NTS 20 (1973): 210-15; William R. Baker, Personal Speech-Ethics in the Epistle of James, in WUNT 2, 68 (Tübingen: J. C. B. Mohr (Paul Siebeck), 1995). On the negative view, see James Adamson, The Epistle of James (NICNT; Grand Rapids: Eerdmans, 1976): 172.

2 William R. Baker, 'Christology in the Epistle of James', EvQ 74 (2002): 47-58; Andrew Chester, 'The Theology of James' in Andrew Chester and Ralph P. Martin, The Theology of the Letters of James, Peter, and Jude (New York: CUP, 1994): 43-44. John Reumann, 'Christology of James' in Who Do You Say That I Am? Essays on Christology, eds. Mark Allan Powell and David Bauer (Louisville: Westminster John Knox, 1999): 128-39. Richard Bauckham, James (New Testament Readings; New York: Routledge, 1999): 25-28.

3 William R. Baker, 'God as Priority in the Epistle of James' unpublished paper presented at Evangelical Theological Society, November, 2003. Douglas J. Moo, The Letter of James (Pillar New Testament Commentary; Grand Rapids: Eerdmans, 2000): 28-29.

4 J. A. Kirk, 'The Meaning of Wisdom in James: Examination of a Hypothesis', NTS 16 (1969): 24. Patrick Hartin, James and the Q Sayings of Jesus (JSNTSS, n. 47; Sheffield: JSOT, 1991): 107, makes a parallel statement. 
aware that he has not made an indisputable case. ${ }^{5}$ Commonly, the article is cited in support of passing comment on the issue. ${ }^{6}$ Davids, one of the leading commentators on James, has extended Kirk's arguments; another, Moo, has argued against Kirk and Davids. ${ }^{7}$ Bauckham appears to support the Kirk/Davids position in his theology of James, while Chester clearly opposes it. ${ }^{8}$

The purpose of this article is to examine Kirk's position and arguments closely as a window into answering the question of whether or not wisdom and Spirit are truly interchangeable and whether, if they are, this allows us to read 'wisdom' in James as if it is the Holy Spirit as developed elsewhere in the NT. The basic conclusion is that Kirk (followed by Davids) has made the case for the importance of Jewish wisdom theology to James but his tantalising claims have too often not been read in the light of his sobering conclusions. At times, he has overlooked important correspondence to the Jesus tradition and has made too much of correspondences to Pauline writings. James' orientation toward wisdom is without regard to the Holy Spirit elsewhere in the New Testament. It should be read as aligning somewhere between Septuagintal wisdom literature ${ }^{9}$ and the Jesus tradition but not extending to the advanced theological thinking represented by Paul.

5 Kirk, 'Wisdom in James', 38. As he states, 'We conclude that such an interchange of terminology is by no means outside the bounds of probability even if this certainty cannot be established.' Also, he states, 'we have found a limited and yet significant number of passages in which either Wisdom and Spirit are directly identified or they are said to have the same function, or Wisdom becomes the supreme and overriding gift of the Spirit.' The last of these possibilities is sustained in his article, but not the other three.

6 James Adamson, James: The Man and His Message (Grand Rapids: Eerdmans, 1989): 380-81; Robert Wall, Community of the Wise: The Epistle of James (New Testament in Context; Harrisburg, PA: Trinity International, 1997): 189; Ralph Martin, James (WBC; Waco, TX: Word, 1988): 38; James Ropes, Epistle of James (ICC; Edinburgh: T \& T Clark, 1920): 133. Donald Gowan, 'Wisdom and Endurance in James' in Horizons in Biblical Theology 15 (1993): 145-53, considers his work supportive of Kirk's work.

7 Peter Davids, Commentary on James (NIGTC; Grand Rapids: Eerdmans, 1982): 51-57; Peter Davids, Theological Perspectives on the Epistle of James', JETS 23 (1980): 103; Moo, James, 34, 175. More recently, Patrick Hartin, James and Q, 10115 , engages the matter, coming down on the side of Kirk and Davids.

8 Bauckham, James, 153; Chester, 'James' in Theology of the Letters, 39.

9 B. R. Halson, 'The Epistle of James: "Christian Wisdom?"' Studia Evangelica 4 (1968): 308-14, long ago in discovering the largest percentage of James' Hapax Legomena in books like Sirach and Job (65\%), established that 'the Epistle of James has a marked predilection for words from the Septuagintal Wisdom Literature' (309). 
To establish this conclusion, this study will examine the Kirk proposal as it argues first from James, then Paul, then Old Testament and inter-testamental literature, including Davids where relevant, and finally examining relevant information from Matthew and Luke regarding the wisdom of Jesus.

\section{Wisdom and Spirit in James}

The Epistle of James is recognised as the closest representation of wisdom literature in the NT. ${ }^{10}$ The author, a teacher (3:1) strategically employs aphorisms $(1: 27 ; 2: 13 ; 3: 18 ; 4: 17)$ to stimulate maturity and re-commitment to God $(4: 1-4)$ in a readership stymied by hardship $(1: 2-8 ; 2: 6 ; 5: 1-6)$ and demoralised by harmfully uncontrolled speech $(1: 19-25 ; 2: 12-13 ; 3: 1-12 ; 4: 1-4,13-16 ; 5: 9,12,16)$. Also like wisdom literature, James promotes the value of obtaining wisdom to be successful in life $(1: 5-8,17)$ and pondering what wisdom is $(3: 13-18)$. This occurs in only two places, but they are both strategic to James' objectives to bring readers to a crossroads where they must choose to live God's way or the world's way. ${ }^{11}$ Examination of these passages is also the focal point for the Kirk/Davids proposal that wisdom in James is equivalent to the Holy Spirit outside of James.

James 1:5 encourages readers to ask God for wisdom, essential for overcoming the various trials of life and growing to maturity. However, as 1:6-8 continues, they must have unwavering trust in God's virtuous character, or he will not respond favourably. Instead, he will leave them to continue in the misery of their unstable pattern of life. If they live through their challenging circumstances with their trust for God intact, he will reward them (1:12-14). But if they question his character

10 Baker, Personal Speech-Ethics, 7-12. Bauckham, James, 29-111; Patrick Hartin, James of Jerusalem (Collegeville, MN: Liturgical, 2004): 88-90; Patrick Hartin, James (Sacra Pagina; Collegeville, MN: Liturgical, 2003): 77; Patrick Hartin, James and Q, 42; Luke Timothy Johnson, The Letter of James (AB; New York: Doubleday, 1995): 33; Ralph Martin, James (WBC; Waco, TX: Word, 1988): lxxxii-lxxxiiii.

11 Hartin, James and Q, 97, declares that 3:13-18 together with 4:1-10 'form the very heart and center of the body of the epistle.' See also Robert Chaffin, Jr, 'The Theme of Wisdom in the Epistle of James', Ashland Theological Journal 29 (1997): 23-49. Against the tide of opinion, Donald Verseput, 'Wisdom, 4Q185, and the Epistle of James', JBL 117 (1998): 691-707, concludes that 'wisdom remains a marginal motif in James.' 
or connect him in any way with their lure toward evil, they will reap the dire consequences of that choice (1:12-15).

Implicit is that God's wisdom in their lives will keep them from living a miserable, unrewarding life. Because God's wisdom is founded on God's good character, it follows that the activities of his creation have a positive trajectory, even if his creatures, including trusting humans, cannot always understand. James 1:17 caps this thought when it says, 'Every good and perfect gift is from above, coming down from the Father of the heavenly lights, who does not change like shifting shadows' (TNIV).

Kirk's first suggestion is that 'the supreme good gift' from God of James 1:17 parallels Luke 11:13, making wisdom in James 'exactly the same conception' as the Holy Spirit in Luke. ${ }^{12}$ Since 1:17 does

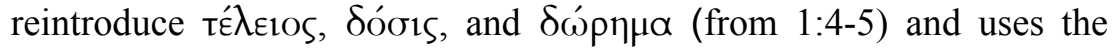
anacoluthon of 'from above' for God as in 3:17, it is certain that wisdom is at least one of the good gifts 1:17 has in mind. ${ }^{13}$ However, to suggest James has in mind the Holy Spirit specifically, or even wisdom as 'the chief gift' as Davids concludes, is a stretch.

First of all, in Luke 11:11 Jesus does speak of the Father in heaven giving the good gift of the Holy Spirit to those who ask, but the context there gives no hint that this has anything to do with wisdom or overcoming trials or temptation. ${ }^{14}$ It appears to be more about God's blessings in the lives of his children. Besides that, the parallel in Matthew 7:11 with 'good gifts' rather than 'the Holy Spirit' is the closer of the two to James, and it is fairly well established from other parallels in James, that the author relies on a version of the Sermon on the Mount tradition similar to Matthew's. ${ }^{15}$ Most commentators

12 Kirk, 'Wisdom in James', 25. See also Hartin, James and Q, 104.

13 Cain Hope Felder, 'Wisdom, Law and Social Concern in the Epistle of James' (Ph.D. Thesis, Columbia University, 1982): 47.

14 Cain Hope Felder, 'Wisdom, Law and Social Concern', 38.

15 Numerous sources recognise the similarity of James' teaching at many points to that of Jesus found in Matthew and Luke. See Davids, James, 47-48. Though Davids emphasises James' closer proximity to Luke, most, like Johnson, James, 56-57; Bauckham, James, 101; Hartin, James, 82; and Ben Witherington, III, Jesus the Sage: The Pilgrimage of Wisdom (Minneapolis: Fortress, 1994): 243-44, see proximity to Matthew predominating. Discussion includes the Q tradition that lies behind Matthew and Luke. The most detailed study of this comes from Hartin, James and $Q$. Witherington, Jesus, 245-46, rightly counters Hartin, James and $Q, 125$, for advocating that Luke's version is closer to the original Q version than Matthew. Hartin, James, 82, himself speaks of Matthew's Sermon on the Mount being closer to original Q than Luke's. 
consider Matthew's version of this saying to be prior to Luke's, ${ }^{16}$ and James demonstrates an affinity with Matthew's version of the Sermon on the Mount at multiple points, including the mutual interest in 'perfection' (James 1:4; Matt. 5:48) and on peacemaking (James 3:1718; Matt. 5:5, 9). Finally, Luke has a special interest in accentuating the Holy Spirit in the gospel as preparation for the Spirit's extensive activity in Acts. Interest in asking for the Spirit in Luke 11:13 is an opportunity to prepare for persecuted disciples relying on the Holy Spirit to teach them what to say before sceptical authorities in Luke 12:12 and numerous situations that follow in Acts.

Second, the way James phrases the Greek (literally, 'every good giving and every perfect gift') does not suggest a single gift but rather incalculable gifts coming out of God's continuous generous nature. The phrasing creates a rhetorical force, ${ }^{17}$ basically, saying the same thing twice, giving the effect of 'each and every gift'.

Third, it is likely that James intends readers to read forward as well as backward from this phrase. This, then, would include as good gifts such things as the 'word of truth' which gives birth to them $(1: 18)$ and the 'implanted word' which they must receive in order to be saved $(1: 21)$, as well as discernment between true and false wisdom in 3:13$18 .{ }^{18}$

James 3:13-18, containing one use of бopós (3:13) and three uses of oopia $(3: 13,15,17)$, is the most focused discussion of wisdom in the epistle. It begins by asking the perennial question, 'How do you know a wise person when you see one?' and moves on to reveal the origin of wisdom and to differentiate false from true wisdom. It teaches that a wise person is one who consistently demonstrates deeds of praiseworthy charity (the word 'good' being from $k \alpha \lambda$ ós here rather than óra $\theta$ ós as in 1:17) flowing out of a humble attitude. This person is feasting on wisdom that comes 'from above' (note parallel to 1:17). A life with actions flowing from envy and selfish ambition

16 I. Howard Marshall, Commentary on Luke (NIGTC; Grand Rapids: Eerdmans, 1978): 470; Daniel Harrington, The Gospel of Matthew (Sacra Pagina; Collegeville, MN: Liturgical, 1991): 103.

17 Johnson, James, 195; Martin, James, 159.

18 Johnson, James, 205. Patrick Hartin, "Who is Wise and Understanding among You" (James 3:13)? An Analysis of Wisdom, Eschatology, and Apocalypticism in the Epistle of James', Hervormde Teologiese Studies 53 (1997): 981, and Hartin, James and $Q, 107$, consider wisdom to envelope each of these terms, but this is not at all clear from the text. 
demonstrates that it is not drawing on wisdom 'from above' but from below, or from false wisdom that is earthly and demonic in nature. This false wisdom is the origin of social disorder and human evil. The true wisdom from God results in peace.

Kirk's suggestion that the Holy Spirit is God's wisdom in 3:9-13 rests on a very tenuous analogy based on understanding the 'spirit' ( $\pi v \varepsilon \tilde{v} \mu \alpha$ ) in 4:5 to refer to the evil nature of humans. He reasons that if this is so, it parallels the evil wisdom of 3:9-13, and since the antithesis of the believer's evil nature is the Holy Spirit, then this is equivalent to wisdom from above in 3:9-13, whose opposite is false wisdom. ${ }^{19}$ Not only is this reasoning tortured, the analogy relies on interpreting 4:5one of the most difficult passages in all of the NT to translate, much less interpret-in one of the least likely ways. ${ }^{20}$ His suggestion that the subject of the verse is God, rather than the spirit never deals with how God can be associated with 'envy' ( $\varphi$ Өóvo $)$, which, unlike 'jealous' is never used of him anywhere in the Bible. ${ }^{21}$ Wisely, Davids does not take up this faulty part of Kirk's analysis.

The stronger of Kirk's arguments from 3:13-18 involves James' list of ten wise attributes in 3:17 with Paul's list of eight fruits of the Spirit in Galatians 5:22-23. However, he overstates his case when he proclaims, 'In this context Wisdom plays exactly the same part as Paul's "fruit of the Spirit". ${ }^{22}$ That inter-community strife, as Kirk asserts, is the occasion for both the list in James and in Galatians is possible, based on Galatians 5:14-15 and James 4:1-2. However, this does not mean that James' list about wisdom and Paul's list about the Spirit are both really about the Spirit.

Moreover, Kirk equivocates, when he says, 'Is not Wisdom in James iii. 17 equivalent to the Spirit in Gal. v. 22, or at least to the fruit of the

19 Kirk, 'Wisdom in James', 26.

20 Johnson, James, 280-81.

21 Johnson, James. In n. 1 he offers this translation for James 4:5: 'He (God) yearns with indignation for the spirit which he has made to dwell in us.' This option is not taken up by any translation. Simply translating mpòs $\varphi \theta$ óvov as 'with indignation' does not overcome the problem that it means envy and is never used of God. For this reason, the spirit is correctly taken to be made the subject. It can still be taken to refer to the human spirit in a negative way as Kirk suggests. However, if taken positively, it patterns the sentiment of Psalms 42:2 and 84:2, which speak of a person 'yearning' (same word in the LXX) for God. This best satisfies the need to find a reference point in the OT for what appears to be at least an indirect quotation.

22 Kirk, 'Wisdom in James', 27. 
Spirit.' ${ }^{23}$ Finally, he views the fact that James 3:17, 18 and Galatians 5:22 use the word 'fruit' (карто́) and James 3:18 and Galatians 6:8

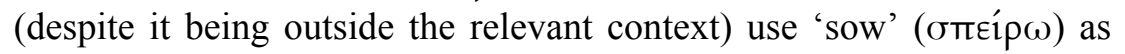
forging an identification of Wisdom and Spirit in the two books. ${ }^{24}$ However, the appearance of these words in both James and Galatians is more probably based on Jesus tradition, such as, 'By their fruit you shall know them' (Matt. 7:20), and the parable of the sower than that Spirit in Paul and wisdom in James are identical. ${ }^{25}$

Kirk never compares the individually listed items in James 3:18 to those of Galatians 5:22-23. Davids, however, does line up the items from the two lists and for good measure includes lists from Matthew 5:3-10 and from 1QS 4:3-6.26 Despite the fact that three items from James and Galatians are virtually the same (humility, peace, and love) and other items from all the lists are similar, he rightly concludes that the lists reveal their authors' common dependence on Judaism rather than that anyone copied from another's list. He makes more of how three of the four lists (James, 1QS, Galatians 5) couch themselves as virtues whose source is God and are immediately contrasted in their contexts with vice lists. He then connects this information back to James 1:2-8 to conclude that wisdom is 'related to standing the test'

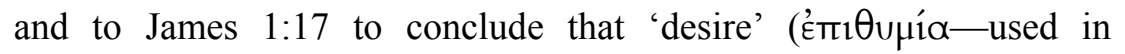
Galatians 5:16 and James 1:14-15) contrasts with wisdom as 'the good gift that leads to life'. ${ }^{27}$ This leads to his overall conclusion that 'James has a wisdom pneumatology, for wisdom in James functions as the Spirit does in Paul: wisdom helps one stand, delivers one from "the flesh" (i.e. epithumia in James), and produces the fruit of the Christian life.'28

First, regarding the listed items, a detailed comparison reveals not only three virtually identical items between James 3 and Galatians 5, it also exhibits three virtually identical items between James 3 and Matthew 5 (humility, peace, and righteousness), two of which overlap

\footnotetext{
23 Kirk, 'Wisdom in James'.

24 Kirk, 'Wisdom in James'.

25 The use of the provocative metaphor of good fruit for the good actions of people is most prominent in Matthew (Matt. 3:8-10; 7:16-20; 12:33; $21: 19-43$ ) but can also be seen in Luke (Luke 3:8-9; 6:43-44) and John (John 15:2-16). It is also found in many of the sowing parables (Matt. 13:3-39; Mark 4:14-32; Luke 8:5).

26 Davids, James, 54.

27 Davids, James, 55.

28 Davids, James, 56.
} 
with Galatians 5 (humility and peace). Does this not suggest the possibility of a common resource more focused in the teaching of Jesus than Jewish culture? Also, the Matthew 5 list exhibits none of the characteristics (gift from God and contrasting vice list) Davids draws from Galatians 5 and 1QS which he applies to James 3. One could just as easily compare - registering that neither of these passages speak of the Spirit whatsoever - the fact that as Matthew 5 lists the traits one must look for to identify people who exhibit the ideals of God's coming kingdom, so James 3 exhibits the observable character traits of people who are wise.

Second, Davids's conclusion from James 1 that wisdom 'is related to standing the test' is accurate, but 'related' is an extremely unfocused term. It is not the same as saying, 'Wisdom is the power from God (like the Holy Spirit) which enables a person to overcome the evil desires presented by temptations in their lives in order to pass the tests of life.' But this is precisely what he needs to show from James 1 to confirm his point of comparison with Galatians 5. James simply does not say what Galatians says. It does not relate wisdom to power or authority over sin the way Paul employs the work of the Spirit in believers.

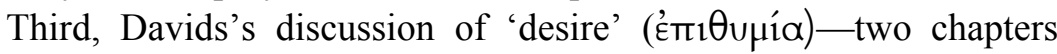
previous to James 3:13-18 - as if it is as contextually connected as Galatians 5:14 is to the fruits of the Spirit list in Galatians 5:22stretches the boundaries of sound contextual interpretation. In order to do so, he would need to establish the links between these distant contexts in James, something he does not do. He does not actually even

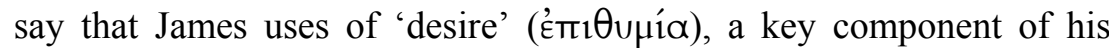
argument, are in James 1:13-15 and not in James 3:13-18.

Fourth, James never connects his so-called 'vice list' in 3:16 with 1:13-15 linguistically. Whereas, it speaks of envy ( $\tilde{\eta} \lambda_{0}$ ), ambition

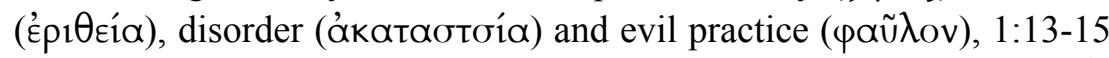

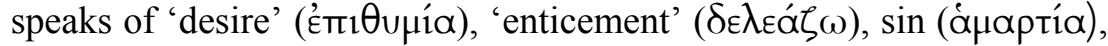
and 'evil' (kakós). Overlapping concepts are employed but never the same word, not even for evil. Also, James' 'vice list' is considerably briefer - containing a mere four items - when those Davids enlists in his support are extremely lengthy; 1QS 4:9-11 lists over 20 items and Galatians 5:19-21 lists over 15 items. Besides, James does not ascribe the four in his list (envy, ambition, disorder, and evil practice) to the influence of a spirit of falsehood or to evil desire. They are a few sample attributes to help discern a person who is not wise from a 
person who is. James never calls wisdom a power from which good attributes flow, with false wisdom being a power from which bad attributes come. The power is God, from whom wisdom must be requested, and these qualities are what wisdom looks like or does not look like. The alternative power or source, having the attributes of being earthly and demonic-like is not even named, as Satan or as anything else. The vacuum created by not calling on God, who imparts wisdom in trying circumstances, allows for this activity which is unlike wisdom.

Neither Kirk nor Davids, then, provide convincing arguments from their analysis of James itself for their conclusion that wisdom in James should be identified as equivalent to the Holy Spirit elsewhere in the NT or in Paul.

\section{Wisdom and Spirit in Paul}

In comparing the Spirit in Paul and wisdom in James, Davids makes only general observations regarding relevant Pauline texts. However, Kirk offers substantial evidence from Paul that invite re-examination. Evaluation of this will be preliminary to a wider look at Paul's doctrine of the Spirit and its comparability with wisdom in James.

In the second section of his article Kirk seeks to show that the 'equation of Wisdom and Spirit in James has its parallels elsewhere in the New Testament. ${ }^{29}$ He begins by identifying four passages he believes identify the person of Christ as the Wisdom of God. Three of these, Colossians 1:15, 1 Corinthians 10:1-4, and Romans 10:6, he acknowledges are no more than allusions. First Corinthians 1:18-31, particularly 1:24 and 1:30, he considers obvious. However, many scholars caution against making such an identification too quickly. ${ }^{30}$ Paul's emphasis in the context is on the message of Christ who 'has become for us wisdom' (TNIV). Also, when he says in 1 Corinthians 2:16 that believers 'have the mind of Christ' he means by this the

29 Kirk, 'Wisdom in James', 28.

30 A. Van Roon, 'The Relation between Christ and the Wisdom of God according to Paul', NovT 16 (1974): 223, cautions against identifying Christ himself with the wisdom of God in 1 Cor. 1-2. Rather the focus is on Paul's gospel of Christ. Birger Pearson, 'Hellenistic-Jewish Wisdom Speculation and Paul' in Aspects of Wisdom in Judaism and Early Christianity, ed. Robert Wilken (London: University of Notre Dame, 1975): 223, concurs, emphasising that the wisdom in 1 Cor. 1-2 is 'the wisdom of God's salvivic plan centring in the cross of Christ.' 
spiritual dynamic to understand and believe the gospel of Christ as opposed to the 'wise' who think it is foolish. The Holy Spirit provides this wisdom, as 2:13 indicates, but Kirk perhaps unintentionally implies a loss of distinction between the two when he concludes, 'True wisdom is equated solely with gift of the Spirit.' 31

Next Kirk focuses on Ephesians 1:17, where Paul remarks that he continually prays that 'the God of our Lord Jesus Christ, the glorious Father, may give you the Spirit of wisdom and revelation so that you may know him better' (TNIV). Kirk correctly observes that the anarthrous 'spirit' ( $\pi v \varepsilon \tilde{u} \mu \alpha)$ does not rule out a reference to the Holy Spirit. Its definiteness he believes is implied by the clear reference to the Holy Spirit in 1:13-14 and that 1:17 states this 'spirit' of wisdom must come from God. It may as well be the Spirit in that case. ${ }^{32} \mathrm{He}$ concludes that 'a mere disposition of the mind or spirit of wisdom can mean nothing in New Testament terms, for it is neutral, unless we know its origin.' 33

Kirk is by no means alone in his interpretation. ${ }^{34}$ In fact, the TNIV and NIV support 'the Spirit of wisdom', though they acknowledge the competing views by placing 'a spirit of wisdom' as an alternative in the footnote. The TEV's 'the Spirit, who will make you wise' probably captures Kirk's view best. However, the NLT makes 'spiritual wisdom' primary and 'the Spirit of wisdom' secondary, and the RSV, NASB, NAB and JB have 'a spirit of wisdom'. ${ }^{35}$ The parallel of Colossians 1:9 works against Kirk because there the wording is 'spiritual' $\left.\pi v \varepsilon \cup \mu \alpha t ı K^{\prime} \varsigma\right)$ is used, not 'spirit' ( $\left.\pi v \varepsilon \tilde{u} \mu \alpha\right)$, yielding 'all spiritual wisdom and understanding'.

Second, Kirk is undoubtedly correct that 'spirit' in 1:17 is not the spirit of natural man and could be right that Paul is thinking of 'Spirit' as the source of any wisdom and revelation to people. However, since Paul is already naming the source as God, a third alternative is worth

31 Kirk, 'Wisdom in James', 31.

32 Kirk, 'Wisdom in James', 30.

33 Kirk, 'Wisdom in James', 30.

34 Harold Hoehner, Ephesians: An Exegetical Commentary (Grand Rapids: Baker, 2002): 256-57; Andrew Lincoln, Ephesians (WBC; Waco, TX: Word, 1990): 57; Peter O'Brien, The Letter to the Ephesians (Pillar; Grand Rapids: Eerdmans, 1990): 131; Markus Barth, Ephesians (AB; 2 vols.; Garden City, NY: Doubleday, 1974): 148.

35 T. K. Abbott, Epistles to the Ephesians and to the Colossians (ICC; Edinburgh: T \& T Clark, 1897): 28, notes that oopía with the genitive following is not likely the Holy Spirit. 
considering. Paul could be using 'spirit' as the true essence of something as a point of emphasis, playing off the word 'Spirit' in 1:13. In this understanding 'wisdom' and 'revelation' are the main point (attributed genitives) and are being complemented by 'spirit'. Paul is praying that they should receive genuine (spiritual) wisdom and revelation that comes only from God so that 'you may know him better'. Though not convinced, Kirk himself notes similar uses as this by Paul such as 'spirit of faith ( 2 Corinthians 4:3) but also 'the spirit of your mind' (Ephesians 4:23) and 'the spirit of righteousness' (Galatians 5:5). Also, despite mentioning words often associated with the Holy Spirit, such as 'power' and 'strength' in 1:19, Paul relates these to the resurrection and not to the Holy Spirit.

Third, if 1:17 is read as meaning the Holy Spirit, the function seems out of sync with $1: 13$. The point of 1:11-14 is that the Holy Spirit is something all believers already have, and continuously have, a guaranteeing deposit of God's possession. If 1:17 is read as the Holy Spirit, then Paul's statement that he continually (present tense) asks God to give them this Spirit (of wisdom) is unnecessary and unwarranted. It seems more likely that he is praying for God to give them daily wisdom and revelation to know God better and please him in their lives. It may be that the Spirit really is the mediator of this communication from God, but this is not the main point, and the two should be absorbed into one another. ${ }^{36}$ Additionally, nowhere does Paul pray for believers to receive the Holy Spirit nor does he encourage believers to pray for the Holy Spirit. He does urge praying 'in the Spirit' (Ephesians 6:8), 'living by the Spirit' (Galatians 5:16), being 'controlled by the Spirit' (Romans 8:6; 8:9), and 'serving in the Spirit' (Romans 7:6). Paul normally assumes that believers already received the Spirit upon their conversion to Christ.

Although Kirk rightly observes that both wisdom in James and the Spirit in Paul are powerful forces from God to overcome temptation and sin that come from the world, ${ }^{37}$ it is best not to confuse the two even in Paul. James for its part does not use the word 'spirit' at all to

36 H. Jaeger, 'The Patristic Conception of Wisdom in the Light of Biblical and Rabbinical Research', Texte und Untersuchungen 79 (1961): 97, suggests that the midrash teaches something very near to this, when he says, 'in a spiritual sense: it is a favourite subject of the midrash that only a man educated on these lines can be pious. Wisdom, therefore, is considered as the capacity for understanding more deeply what the indwelling divine spirit teaches the soul.

37 Kirk, 'Wisdom in James', 30-31. 
make this emphasis. Rather, James' stirring emphasis in 1:2-8 is that believers toiling under the various pressures of life must ask God for his wisdom from time to time in order to emerge strengthened and victorious. If they do not they will tend to blame God for their troubles and diminish in their faith. God will give wisdom freely-and it is one of God's gifts to be treasured. However, it is not one-time infusion like the Holy Spirit in Paul; rather, like wisdom in Paul it is a perennial offer, always on the table to be requested and provided over and over again, since the hardships and confusions of life come and go and return. James envisages a repetitive cycle of personal trials, requests for God's wisdom, and perseverance that brings believers to their optimum measure of maturity.

Praying for God's wisdom amid life's struggles in James, then, should not be confused with the role of the Holy Spirit who abides in believers permanently and need not be requested for repetitively. The Spirit already residing in believers may be the means by which God provides this requested wisdom. ${ }^{38}$ However coordinated or symbiotic the two are, it is best not to blur the Spirit's distinctive role as medium and wisdom's function as message. This is particularly so in James who only speaks of wisdom.

\section{Wisdom and Spirit in Jewish Literature}

In the third section of his article Kirk seeks to demonstrate that the Spirit and Wisdom are linked in the Old Testament and Intertestamental Literature and that this provides the foundation for understanding James' concept of wisdom as equivalent to that of the Spirit elsewhere in the NT. His important demonstration that spirit and wisdom are employed in some comparable contexts, however, does not establish their equivalence in those contexts.

Kirk begins by pointing to passages that suggest the Spirit to be God's agent in creation (Genesis 1:1; Psalm 33:6) and in sustaining the creation (Job 34:14; Psalm 104:30) and other passages that speak of wisdom as have a role in creation (Proverbs 8:22-31; Wis. 7:22; 13:1;

\footnotetext{
38 Abbott, Ephesians and Colossians, 28, suggests this also. Mariam Kamell, 'Wisdom in James: An Examination and Comparison of the Roles of Wisdom and the Holy Spirit' (M.A. thesis, Denver Seminary, 2003): 73, suggests Job 32:8 as a passage which would support such a relationship between Spirit and wisdom.
} 
Sir. 24:3-5). ${ }^{39}$ First, Kirk provides no examples of wisdom in the role of sustainer, though he lists it as a comparable function of wisdom and the Spirit.

Second, his examples of wisdom's role in creation from Proverbs and Wisdom of Solomon both write of the wisdom as God's

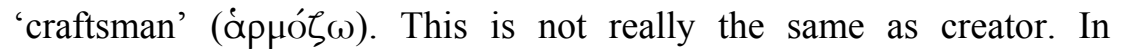
addition, in Proverbs wisdom is also said to be 'the first of his works' (8:22), created before everything else was created (8:24-29). The Spirit of God could not be interchanged with such thoughts. Both the Proverbs and Wisdom passages, in fact, employ expansive personifications of wisdom that never separate wisdom as an agent independent from God. ${ }^{40}$ Yet, it would not be improper to speak of the Spirit of God as an elaborate personification of God.

Third, Kirk correctly points out that Ben Sira 24:3 alludes to Genesis 1:2 and 2:6 when Wisdom declares, 'From the mouth of the Most High I came forth and like a mist covered the earth,' but six verses later, Ben Sira 24:8 parrots Proverbs 8:23 when Wisdom says, 'Before all the ages, in the beginning, he created me.' This, again, is not interchangeable with the Spirit of God.

Fourth, wisdom in Proverbs, Sirach, and Wisdom of Solomon consistently is described as female, whereas as God and the Spirit of God are portrayed as male. This makes their complete identification unlikely. ${ }^{41}$

Fifth, Psalm 33:6 does not describe the Spirit of God as an agent in creation but affirms 'the word of the Lord' as making the heavens, paralleled with 'the breath of his mouth' making the stars. Kirk assumes that 'breath' (רוח) refers to the Spirit as it does in Genesis 1:2

\footnotetext{
39 Kirk, 'Wisdom in James', 32.

40 Witherington, Jesus, 44. K. A. Farmer, Proverbs and Ecclesiastes (Grand Rapids: Eerdmans, 1991): 54, Witherington, Jesus, 51, adds that wisdom is 'an aesthetic device meant to stress the moral beauty and personal character of God's wisdom as opposed to other kinds of so-called worldly wisdom'. F. W. Dillistone, 'Wisdom, Word, and Spirit', Int 2 (1948): 281, in his classic analysis of spirit and wisdom in Jewish and Christian literature, commenting on Wis. 6:12; 7:22-27, says, 'What we do not find, however, is any approach to a personalisation or even to an hypostatisation of Wisdom. She is likened to God's breath, she is compared to the bright rays emanating from the sun. But she is in no way an independent or even a cooperative agent of creation. We may without hesitation affirm the author is speaking metaphorically when he refers to the beauty and the purity and sympathy of the Wisdom of God.'

41 Dillistone, 'Wisdom', 287.
} 
but offers no explanation. The TNIV, NIV, NASB, NRSV, NAB, ESV translate it as 'breath'.

Kirk adds Exodus 28:3 and 31:3 as well as Deuteronomy 34:9 as equating Wisdom with the Spirit. The word 'wisdom' in Exodus 28:3 is used of people having the skill to sew garments and being filled 'with the Spirit of God' in Exodus 31:3 is named as enabling people with proficiency in crafting products. But these are not even remotely spiritual experiences comparable to the function of wisdom or the Spirit in the NT or in James. Deuteronomy 34:9 narrates that after Moses laid his hands on him, Joshua received 'the spirit of wisdom'. Kirk takes this to refer to the Holy Spirit. However, most translations choose the lower case for 'spirit'. ${ }^{42}$ As in Ephesians 1:17 the emphasis should be seen to be on 'wisdom', and this is confirmed by the note that the Israelites 'listened to him'. Joshua received the spirit of wisdom in the sense of being able to articulate wise decisions and guidance in his leadership as Moses did.

Kirk mentions Isaiah 11:2, and Davids concludes that in this passage, 'Spirit and wisdom are linked.' In this messianic passage, Isaiah contends that the Messiah will come from the line of David (or Jesse, his father), exclaiming, 'The Spirit of the Lord will rest on him, the Spirit of wisdom and of understanding.' The two are paralleled here. Yet, the passage does go on to add 'the Spirit of counsel and of might, the Spirit of knowledge and fear of the Lord.' All these attributes - wisdom, understanding, counsel, might, knowledge, and fear of the Lord-emanate from someone whom the Spirit of God inhabits. But wisdom is not distinguished as superior to the other attributes because it is the Holy Spirit of Wisdom and the others are not. ${ }^{43}$ In fact, the Spirit of the fear of the Lord is the one underscored in 11:3 when it says 'and he will delight in the fear of the Lord'. Wisdom is merely one attribute, but this does not amount to wisdom here being equivalent to the Holy Spirit unless each of these attributes are understood this way.

Davids adds Genesis 41:38-39 as evidence for linking Spirit and wisdom where it speaks of Joseph as having 'the spirit of God' and being 'wise and discerning'. ${ }^{44}$ First, this is another passage plagued

42 NIV, TNIV, NLT, NRSV, NASB, NAB all have 'spirit of wisdom'.

43 Edward J. Young, The Book of Isaiah (3 vols.; Grand Rapids: Eerdmans, 1965): $3: 382$, notes 'None of the terms employed is entirely exclusive of the others.'

44 Davids, James, 52. 
with translation issues. The Pharaoh's reference to God is certainly polytheistic in scope. Thus, the NASB offers 'a divine spirit' and NIV adds as an alternative 'spirit of the gods'. ${ }^{45}$ In other words, this is not a reference to the one, true, living God of the Hebrews, much less to the Holy Spirit of that God. ${ }^{46}$ Even the lower case 'spirit' in most translations suggests that this is not the Holy Spirit. That Joseph displays wisdom is no doubt, but this is an attribute of his devotion to God and is not a reference to the Spirit of God.

Unquestionably, James' understanding about wisdom is compatible with ideas about wisdom found in previous Jewish literature. The problem is that James articulates absolutely no ideas about the Holy Spirit. To say, as Kirk and Davids do, that these compatible ideas about wisdom mean that ideas about the Holy Spirit in this literature then are equivalent to James' concept of wisdom does not necessarily follow.

Wisdom 7:22-30 typifies Jewish thought. In the midst of a lengthy sonnet to wisdom, wisdom is spoken of as 'a spirit' but not 'the Spirit'. The reason for calling wisdom 'a spirit' is what the listed qualities are intended to explain. Wisdom has the qualities of a person who possesses a spirit. Thought of as female, she is an ideal person, like God, but is not identified with the Holy Spirit of God. It says, 'For in her is a spirit: intelligent, holy, unique, manifold, subtle, agile, clear, unstained, certain, not baneful, loving the good, keen, unhampered, beneficent, kindly, firm, secure, tranquil, all-powerful, all-seeing, and pervading all spirits, thought they be intelligent, pure and very subtle'. Wisdom pervades all spirits in the sense that all persons, who also are animated by a spirit, have access to her or may be influenced by her.

The idea of praying for and seeking wisdom abounds in Jewish wisdom literature. Wisdom 7:7-8 recounts that Solomon 'prayed and prudence was given,' 'pleaded and the spirit of Wisdom came.' Wisdom 8:2 adds, 'I loved her and sought after her from my youth.' Sirach 51:13 says 'When I was young and innocent, I sought wisdom. She came to me in her beauty and until the end I will cultivate her.' Sirach 1:1 says, "All wisdom comes from the Lord and with him it remains forever.

Following Sirach 1, which encourages seeking wisdom from God, Ben Sira 2:1-6 provides the closest parallel to the encouragement of

45 NLT, NRSV, NIV, NAB all have 'spirit of God'.

46 G. Ch. Alders, Genesis (Bible Student's Commentary; 2 vols; Grand Rapids: Zondervan, 1981): 2:215. 
James 1 to seek God's wisdom during life's trials: 'My son, when you come to serve the Lord, prepare yourself for trials. Be sincere of heart and steadfast, undisturbed in time of adversity. Cling to him. Forsake him not; thus will your future be great. Accept whatever befalls you, in crushing misfortune be patient. For in fire gold is tested, and worthy men in the crucible of humiliation. Trust God and he will help you; make straight your paths and hopes in him.'

Jewish wisdom literature, then, contains plenty of material to explain James' perspective on wisdom without involving any notions about the Holy Spirit. The Holy Spirit and wisdom are not invariably packaged together nor incontrovertibly equated in this literature. So, it cannot be assumed, as Kirk and Davids do, that the Holy Spirit follows alongside wisdom when it appears in the OT or in James. As Chester concludes, 'Within Judaism, it was quite possible to speak of wisdom without implying reference to the spirit, and this is so for James.' ${ }^{2} 7$

\section{The Wisdom of Jesus in Matthew and Luke}

In his classic book on NT theology, Stevens makes an astute, general observation regarding the Epistle of James, 'It reads like a Jewish sapiential book, but the wisdom which is commended is the wisdom of Jesus. ${ }^{4}$ Without identifying even one quotation or thought as being dependent on Jesus, James repeatedly employs language that echoes what can be observed especially in Matthew. ${ }^{49}$ Analyzing what these gospels convey regarding Jesus' thoughts about wisdom would appear, then, to be a worthwhile approach. This section extends the brief treatment provided by Kirk and Davids. ${ }^{50}$

Luke describes the infant Jesus as 'filled with wisdom' $(2: 40)^{51}$ and from childhood growing 'in wisdom' (2:52), demonstrated by his profound inquisitiveness at the temple when he was twelve (2:46). Both Matthew 13:54 and Mark 6:2 depict Jesus returning to Nazareth from his initial travels, only to hear his astounded neighbours react by

47 Chester, 'James' in Theology of the Letters, 39.

48 George Barker Stevens, The Theology of the New Testament (Edinburgh: T. \& T. Clark, 1899): 279.

49 See n. 15 above

50 Kirk, 'Wisdom in James', 25; Davids, James, 53.

51 Jesus is also described in Luke 1:15 as filled with or by the Holy Spirit, but these are not implied to be equivalent experiences. 
saying, 'Where did this man get this wisdom?' His key pronouncements about wisdom itself are rendered as, 'The Queen of the South will rise at the judgment with this generation and condemn it; for she came from the ends of the earth to listen to Solomon's wisdom, and now one greater than Solomon is here' (Matt. 12:42//Luke 11:31) and when he says, 'Wisdom is proved by her actions/children.' (Matt. $11: 19 / /$ Luke $7: 35)$. In the first, Jesus claims to be the wiser than the wisest man with teaching that is paramount for all to hear. The second is more of a 'puzzler' but probably means that despite his rejection by many, Jesus continues to invite people to embrace the wisdom of his message and his person, which will prove itself in their lives if they give it opportunity. ${ }^{52}$

Luke 21:15 emphasises that Jesus himself will supply his persecuted disciples with irresistible wisdom at the crucial moments. This is complemented by Stephen in Acts 6-7 who epitomises the seven appointed deacons 'full of the Spirit and wisdom' (6:3) whose wisdom his listeners and soon-to-be-executioners could not withstand (6:10) and whose defiant speech adulates both the wisdom of Joseph $(7: 10)$ and that of Moses (7:22).

Although this is not a great deal of material in itself, when combined with other aspects of Jesus' life and ministry in the gospels, it is enough for most to conclude that Jesus wants people to view him as a wise man who imparts wise teaching about how best to live and that he himself in an exceptional way envelopes wisdom in his very person, meaning, he identifies wisdom with himself. ${ }^{53}$ This is an avenue of seeing him as God's special messenger (his very son) since God is the source of all wisdom. ${ }^{4}$ As he speaks God's message, he embodies God's wisdom. Of course, he is also filled with the Spirit as are his

52 The enigma the proverb poses in the context is recognised universally. Disparity even occurs as to how it is to be applied. Are Jesus and John the children constantly trying to get the people to play (and thus gain wisdom or act wisely) or are the children contrasting those in 'this generation' who do not repent? The latter interpretation is advocated by Arland Jacobson, 'Wisdom Christology in Q' (Ph.D thesis, Claremont Graduate School, 1978): 90-91; and James Robinson, 'Jesus as Sophos and Sophia' in Wilken, Aspects, 5. The stronger position is the first, consistent with the dirge being played by John the Baptist and the wedding song by Jesus, advocated by Hartin, James and $Q, 123-24$.

53 Robinson, 'Jesus as Sophos and Sophia' in Wilken, Aspects, 9, comments, 'Jesus is not simply cast in the role of one of Sophia's spokesmen, even the culminating one, but rather is described with predications that are reserved for Sophia herself.'

54 Robinson, 'Jesus as Sophos and Sophia' in Wilken, Aspects, 10. 
disciples, which suggests at least their symbiotic relationship but not necessarily their equivalence as Kirk wants to suggest.

Witherington observes that Jesus 'teaches in recognisable sapiential form,' referring to his extensive use of aphorism, beatitudes, and riddles, and proposes that 'the best overall categorisation of the man is that he was a sage. ${ }^{55}$ Among many others, Robinson would go a step further to say that 'Jesus is not simply cast in the role of one of Sophia's spokesmen, even the culminating one, but rather is described with predications that are reserved for Sophia herself.' 56

That James sees himself as a special recipient of Jesus' wisdom like Stephen is difficult to say. He does view himself as a teacher (3:1), and he does depend so much on his understanding of Jesus' teaching that it can be said, as Bauckham does, that 'James appropriates material from the wisdom tradition in a way that is guided and shaped by Jesus' wisdom.' ${ }^{57}$ This causes him to intensify the moral demands of Jesus, as he does regarding personal speech ethics. James employs aphorisms and beatitudes like Jesus and relies heavily on Jesus' wisdom. However, he never attributes any of his own teaching it to dependent on Jesus because wisdom materials, particularly proverbs, were normally imparted anonymously. Thus, Witherington observes, 'James handles Jesus tradition as though it were proverbial Wisdom.' 58

Bauckham finds that James' perspective on wisdom compares more favourably in some important respects with Jesus than with Jewish wisdom generally. ${ }^{59}$ Like Jesus' ethical demands, James tends to challenge conventional wisdom, as in the charge to keep the whole law (2:8-12), to both hear and do $(1: 22-25 ; 2: 16-22)$, and to view a person's speech ethics as a gauge of their entire moral character $(1: 19,26 ; 3: 1-$

55 Witherington, Jesus, 159, 141.

56 James Robinson, 'Jesus as Sophos and Sophia' in Wilken, Aspects, 9

57 Bauckham, James, 153.

58 Witherington, Jesus, 247. Hartin, James of Jerusalem, 102, notes, 'James has taken a Jesus saying and reworked it into his own argumentation in such a way that it would evoke the Jesus saying in the minds of the hearers/readers, but it would be expressed formally in a new way conforming to the context of the argument James is making. Hartin refers to Wesley Wachob, The Voice of Jesus in the Social Rhetoric of James (SNTSMS 106; Cambridge: CUP, 2000): 116, who concludes that using the voice of an authoritative text was a common rhetorical ploy in the ancient world to bolster the validity of a current teaching.

59 Bauckham, James, 97-105. See also, Richard Bauckham, 'James and Jesus' in The Brother of Jesus, ed. Bruce Chilton and Jacob Neusner (Louisville: Westminster John Knox, 2001): 100-37. 
$12 ; 4: 11-12 ; 5: 9,12) .{ }^{60}$ Like Jesus' reversal of social hierarchy and status, James also condemns the rich and commends the poor (1:9-11; $2: 1-7 ; 4: 2 ; 5: 1-6) .{ }^{61}$ Like Jesus' emphasis on God's judgment and his own imminent return as motive for moral behaviour and hope for this worldly injustice, James projects the coming of Jesus (5:7-8) and his function as judge (5:9) as crucial to impel appropriate behaviour in believers. ${ }^{62}$ At the same time, both Jesus and James characterise God as generous and compassionate $(1: 5,17-18 ; 2: 13 ; 4: 6 ; 5: 11)$. Finally, Jesus' concern to reconstitute Israel as God's people is strongly echoed in James' efforts to reconstitute early Jewish Christians into this singular community of God $(1: 1 ; 4: 7-12){ }^{63}$

Although seeing some comparison between Jesus' wisdom and James, Witherington identifies at least one important distinction-the Kingdom of God. ${ }^{64}$ James does not draw on Jesus' wisdom and ethics that celebrate the reordering of life because of the Kingdom of God has come. He is more interested in calculating boundaries between the believing community and the unbelieving or insufficiently believing community. Because of this, Witherington considers James' wisdom to be more compatible with Jewish wisdom represented by Sirach than with Jesus.

Whereas Jesus speaks wisdom and identifies himself with wisdom, his relationship to the Holy Spirit is not portrayed in these terms. He is filled with the Spirit (Luke 1:15), baptised with Holy Spirit (Matt. 3:11) led by the Spirit (Matt. 4:1), empowered by the Holy Spirit (Luke $4: 14 ; 2: 27$ ) and the Holy Spirit comes upon him (Luke 1:35; 4:18). The Holy Spirit is the power of God in his life, but Jesus does not identify himself as the Holy Spirit nor does he speak of his teaching as the teaching of the Holy Spirit.

A crucial statement in terms of the discussion of wisdom and the Spirit in James comes in Luke 11:11, where instead of Jesus

60 Baker, Personal Speech-Ethics, entire.

61 Hartin, James, 85-86, also notes James' continuity with Jesus in its concern for the poor.

62 Darian Lockett, 'The Spectrum of Wisdom and Eschatology in the Epistle of James and 4Qinstruction', TynB 56.2 (2005): 131-48, shows that wrapping eschatological concerns within larger sapiential concerns as James does is typical of this period and is also seen in the key wisdom writing in the Dead Sea Scroll collection.

63 Hartin, James, 86, also observes that James' vision of his mission as focused on his own people, Jews, also coincides with Jesus' perspective.

64 Witherington, Jesus, 246. 
encouraging his disciples to ask the Father for 'good gifts' in Matthew 7:11 it reads that they should ask him for 'the Holy Spirit'. As noted earlier, for Kirk and Davids, this trade-off of terms is key to the conclusion that the good gift James encourages readers to request 'from above' in 1:17 is the Holy Spirit, ${ }^{65}$ but it is more likely that James does not know Luke's rendering.

James, then, lines up favorably, though not completely, with Jesus on wisdom, viewing him as his master teacher. However, he does not go so far as to align wisdom with an imparting of the Spirit, as Luke or Acts do. As with many other issues, including salvation, ${ }^{66}$ James' perspective seems to be entrenched in Jesus tradition best represented in Matthew rather than Luke, with almost no bleeding over into a postPentecost perspective. James' lack of interest in even identifying Jesus with wisdom demonstrates its typical lack of theological development. James is content to incorporate Jesus' exacting ethical wisdom into his own teaching supported by traditional Jewish wisdom teaching. In so doing, it resembles the work of any rabbinic teacher who incorporates the wisdom of his own master teacher and those even before him.

\section{Conclusion}

Kirk's claim for the equivalence of wisdom in James with the Spirit elsewhere and Davids' concept of 'wisdom pneumatology' in James do much to demonstrate the core of Jewish wisdom theology that undergirds James. They rightly draw attention to the correspondence between the two terms in both testaments. Wisdom and the Holy Spirit may be symbiotic in function, especially in disciples of Jesus, but distinction between the two for the most part is maintained. To call them 'more or less interchangeable' as Kirk does ${ }^{67}$ is to imply that it does not matter which one has. To say that God's wisdom is 'virtually

65 Kirk, 'Wisdom in James', 25; Davids, James, 55.

66 Matt Jackson-McCabe, 'The Messiah Jesus in the Mythic World of James', JBL 122 (2003): 701-30, understands the 'world' of James to be more akin to the messianic world of Jewish literature than that of most of the NT, including matters of salvation. Hartin, 'Who is Wise', 969-99, considers James closely aligned to the world of the Q tradition than anything else. Jackson-McCabe and Hartin disagree on whether 'rebirth' has a role in James' salvation narrative, Hartin thinking it is central, Jackson-McCabe thinking it is obscure.

67 Kirk, 'Wisdom in James', 24. 
identical' with being filled with the Holy Spirit, as Davids does, ${ }^{68}$ unnecessarily obscures their biblical distinctions. To show that the Spirit and wisdom are compatible in many biblical and extra-biblical contexts does not necessitate that they are interchangeable or that James would not be perplexed if readers read wisdom concepts as being equivalent to the Holy Spirit.

First, James never refers to the Holy Spirit. Second, passages in Paul presented to establish their equivalence are not indisputable. Evidence is clearer that Paul does not mingle the two, but views wisdom as God's message mediated through the Spirit. He parallels the role of Christ and Wisdom in his hymns but not the Spirit and Wisdom (Philippians 2:6-11; Colossians 1:15-20). ${ }^{69}$ Third, although wisdom and Spirit may overlap in some ways in the OT and other Jewish literature, it is not clear that they are interchangeable even there. Fourth, James appears much more aligned with Matthew than Luke regarding Jesus' teaching about wisdom and does not follow Luke's advanced interest in the Holy Spirit. Fifth, James itself makes no identification of wisdom with the Spirit.

An important contrast between wisdom and the Spirit needs to be recognised. In the NT, the Spirit permanently indwells believers; wisdom is temporary, transitory. This transitoriness of wisdom is one of the most consistent attributes of wisdom in Jewish wisdom literature from Proverbs to Sirach. Wisdom must be sought; it must be searched for; it must be requested; it is fleeting; it is needed from circumstance to circumstance; no human possesses it permanently. This becomes especially so when God is acknowledged as the only source of true wisdom. Wisdom can only be acquired as he makes it available.

Jesus himself personifies wisdom, but he leaves his followers the Holy Spirit as a permanent residential gift. The Spirit may provide wisdom. But the Spirit - not wisdom - provides the power to overcome sin or do miracles. In the pre-NT era, wisdom and the Spirit are closer to each other. However, in the NT era, the role of the Spirit expands while that of wisdom remains relatively unchanged. The Spirit may acquire some of wisdom's function, as seen in Paul. However, James' view of wisdom is largely uninfluenced by Paul and does not tread on

68 Davids, James, 153.

69 Witherington, Jesus, 249-94, demonstrates that as the early Christian community seeks to offer praise and worship to Christ as the Son of God, they borrow from ready to hand hymns to Wisdom from Jewish tradition. 
his highly developed theological world. Alhough neither Kirk nor Davids intend to violate James by reading it through the eyes of Paul as Luther did, their claims amount to an observation that Paul's concept of the Holy Spirit is found there in essence. As Johnson and Bauckham emphasise, James' theology does not require a reference point in Paul's theology to be justified. ${ }^{70}$ James can profitably be read on its own terms.

James is surrounded by the world of Jesus and Judaism. In those worlds, wisdom and the Spirit both are associated with God or with Jesus but are not equivalent. James is James and has its own place in the NT. And, into the world of this epistle the Holy Spirit does not enter. Whatever James says about wisdom is about wisdom.

70 Johnson, James, 111; Bauckham, James, 113-40. 